\title{
An Asian Perspective of the Management of COVID-19: the Asian National Cancer Centers Alliance Led Regional Comparison
}

Luh Komang Mela Dewi ${ }^{\mathrm{a} 1}$, Laureline Gatellier ${ }^{\mathrm{a} 2}$, Kanaga Sabapathy ${ }^{3}$, C S Pramesh $^{4}$, Min Dai ${ }^{5}$, Tran Thanh Huong ${ }^{6}$, Murat Gultekin ${ }^{7,8}$, Erdenekhuu Nansalmaa ${ }^{9}$, Khin Khin Htwe ${ }^{10}$, Aasim Yusuf ${ }^{11}$, Mamak Tahmasebi ${ }^{12}$, Kishore Kumar Pradhananga ${ }^{13}$, Jong Bae Park ${ }^{14}$, Suhaila Md Hanapiah ${ }^{15}$, Suleeporn Sangrajran ${ }^{16}$, Rajendra Prasad Baral ${ }^{17}$, Achmad Mulawarman Jayusman', Satoshi Iwata ${ }^{2}$, Jin Wei Kwek ${ }^{3}$, Manju Sengar ${ }^{4}$, Girish Chinnaswamy ${ }^{4}$, Jie He ${ }^{\text {, }}$ Gu Tian', Phung Thi Huyen ${ }^{6}$, Tran Van Thuan ${ }^{6}$, Bayarsaikhan Luvsandorj', Yi Yi Myint ${ }^{10}$, June Young Chun ${ }^{14}$, Jong Soo Han ${ }^{14}$, William Ying Khee Hwang ${ }^{3}$, Nina Kemala Sari ${ }^{118}$, Tomohiro Matsuda ${ }^{2}$

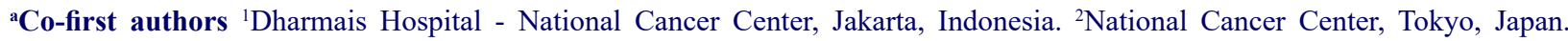
${ }^{3}$ National Cancer Centre Singapore, Hospital Crescent, Singapore. ${ }^{4}$ Tata Memorial Centre, Homi Bhabha National Institute, Mumbai, India. ${ }^{5}$ National Cancer Center, Beijing, China. ${ }^{6}$ National Cancer Institute, National Cancer Hospital, Hanoi, Vietnam. ${ }^{7}$ Hacettepe University Faculty of Medicine, Ankara, Turkey. ${ }^{8}$ National Cancer Institute (TUSEB), Turkish Ministry of Health, Ankara, Turkey. ${ }^{9}$ National Cancer Center of Mongolia, Ulaanbaatar, Mongolia. ${ }^{10}$ Myanmar Yangon General Hospital, Yangon Region, Myanmar. ${ }^{11}$ Shaukat Khanum Memorial Cancer Hospital \& Research Centre, Lahore, Pakistan. ${ }^{12}$ Cancer Institute, Tehran University of Medical Sciences, Tehran, Iran. ${ }^{13}$ Kathmandu Cancer Center, Tathali, Bhaktapur, Nepal. ${ }^{14}$ National Cancer Center of Korea, Seoul, Korea. ${ }^{15}$ National Cancer Institute, Putrajaya, Malaysia. ${ }^{16}$ National Cancer Institute, Ratchathewi Road, Bangkok, Thailand. ${ }^{17}$ Norvic International Hospital, Thapathali, Kathmandu, Nepal. ${ }^{18}$ Faculty of Medicine, University of Indonesia, Jakarta, Indonesia.

\begin{abstract}
Objective: To describe how the Asian National Cancer Centers Alliance (ANCCA) members preserve high standards of care for cancer patients while battling the COVID-19 pandemic and to propose new strategies in the Asian Cancer Centers' preparedness to future pandemics. Methods: A 41-question-based survey was developed using an online survey tool and conducted among 15 major Asian National Cancer Centers, including 13 ANCCA members. Direct interviews of several specialists were conducted subsequently to obtain additional answers to key questions that emerged during the survey analysis. Result: Institution/country-specific results provided a strong insight on the diverse ways of managing the pandemic around Asia, while maintaining well-balanced cancer care. Pragmatic strategies were put in place in each NCC hospital, including zoning and intensive triage depending on the pandemic impact. Distancing strategies and telemedicine were implemented in different capacity depending on the national healthcare system. In addition, there was a diverse impact on the manpower and financial aspect of cancer care across surveyed NCCs relating to magnitude of the pandemic impact on the country. Conclusion: The priorities nevertheless remain on maintaining cancer care delivery while protecting both patients and health care workers from the risk of COVID-19 infection. The role of a think-tank such as ANCCA to help share experiences in a timely manner can enhance preparedness in future pandemic scenarios.
\end{abstract}

Keywords: Asia- cancer- cancer center- Coronavirus- COVID-19- patient

Corresponding Authors:

Luh Komang Mela Dewi and Laureline Gatellier, $\mathrm{PhD}$

${ }^{1}$ Dharmais Hospital - National Cancer Center, Jakarta, Indonesia. ${ }^{2}$ National Cancer Center, Tokyo, Japan.

Email: Lkmeladewi@gmail.com, lgatelli@ncc.go.jp 


\section{Introduction}

The current coronavirus pandemic has created a global crisis. The severe acute respiratory syndrome coronavirus 2 (SARS-CoV-2) virus, which caused Coronavirus disease 2019 (COVID-19), is a novel coronavirus first detected in Wuhan, China in December, 2019 [1]. As of 13-July 2020, over 570,000 people have died from COVID-19 related disease with more than 13 million people being infected globally. Of them, 3 million cases and over 70,000 deaths have been described in the Asia region, representing a global share of $23.21 \%$ and $12.42 \%$ for incidence and mortality, respectively [2]. Report from WHO-China Joint Mission on COVID-19 showed that comorbid conditions such as cardiovascular disease, diabetes, hypertension, chronic respiratory disease, and cancer lead to poor clinical outcomes and higher mortality rates compared to patients without comorbid concerns [3]. The immunocompromised status of cancer patients caused by both the malignancy and anticancer therapies (chemotherapy, surgery, and radiotherapy) increases the likelihood to develop severe complications of COVID-19. Growing evidence from several countries particularly China, Italy, and United Kingdom have reported cancer as a major risk factor for adverse outcomes of and death from COVID-19 [4-6].

Rapid spread and epidemiological novelty of coronavirus infection have brought unprecedented challenges to the healthcare systems globally. Healthcare professionals have been urged to re-organize healthcare systems, sometimes without sufficient scientific evidence available at the beginning of the pandemic. Cancer providers need to alter care delivery models in order to handle the COVID-19 crisis as well as to protect patients without compromising cancer outcomes. Over time, various strategies have been initiated and proposed, including the countrywide strategic preparedness and response plan suggested by WHO; access to resources specific for cancer patients with COVID-19 provided by several organizations including the Union for International Cancer Control (UICC); and research recommendation and initiatives were made available on International Agency for Research on Cancer (IARC) and the United States National Cancer Institute (NCI) websites.

The Asian National Cancer Centers Alliance (ANCCA) was established in 2005 as an initiative to embark together to fight against cancer. With 14 leading cancers institutions in Asia (mostly National Cancer Centers (NCC) recognized by their respective Ministries of Health), ANCCA is the official group of leading cancer centers in Asia that serves as hub and driver to promote collaboration among ANCCA members as well as with multiple stakeholders in cancer care and prevention [7]. The COVID-19 pandemic triggered a regional collaborative effort led by ANCCA member countries, namely NCC-China, NCC-Indonesia, NCC-Japan, NCCKorea, NCC-Mongolia, NCC-Singapore, NCC-Vietnam, as well as Institut Kanser Negara (NCI-Malaysia), National Cancer Institute (NCI)-Thailand, NCI-Turkey and Hacettepe Oncology Institute (NCI-Turkey-HOI), Tata
Memorial Centre (India-TMC), Nepal Kathmandu Cancer Center (Nepal-KCC), Shaukat Khanum Memorial Cancer Hospital \& Research Centre (Pakistan-SKCC), and with the collaboration of two other Asian institutions from Iran and Myanmar (Iran Tehran Cancer Institute (Iran-TCI) and Myanmar Yangon General Hospital (Myanmar-YGH), to summarize, compare and discuss the different strategies in managing cancer-care that were tailored based on country's pandemic preparedness, state of epidemic curve, political and economic status of each country.

Among the ANCCA member countries, the emergence of COVID-19 varied in extent and time, represented by various dates of national emergency declaration, depicted from 24-January 2020 for China to 7-April 2020 for Japan (Figure 1). One trend that became apparent was the prompt governmental action by early responders (January - February) to the pandemic (by time of declaration: China, Mongolia, Malaysia, Singapore, Iran, and Korea), highlighted by the date of emergency declaration and occurrence of COVID-19 cases in each of these countries. In general, the course of COVID-19 pandemic and the actual encounter of COVID-19 patients in NCCs defined the context in which each institution developed and implemented its plans (Table 2). Adding to the complexity to manage the circumstances and adapt its strategies to re-organize the delivery of cancer care while going through the pandemic management were other factors such as the geographic location; status of emergency state declaration; country population; and population density or land area.

With the NCCs needing to handle challenges in adopting new ways of cancer delivery, the ANCCA facilitated the sharing of strategies to preserve high standards of care through regular video conferences among members and making available resources/materials related to COVID-19 on the ANCCA website. This paper is an extension of the sharing efforts and describes actions taken by thirteen ANCCA members and two collaborative members to re-organize cancer services by balancing the COVID-19 specific implementation strategies.

\section{Materials and Methods}

Through regular interactions, ANCCA members decided to join forces in response to the COVID-19 pandemic by designing and distributing an online survey to 14 ANCCA members, and to 5 non-members cancer institutes in the Asia region. The aim of the survey was to assess the short- and longer-term impacts of the pandemic on Asian cancer centers' activities as well as implemented strategies and countermeasures through a set of 41 questions divided into 6 categories.

The online survey tool was used to collect both open-ended and closed-ended questions (multiple choice and rating scale choice questions) to congregate relevant data from respondents. The qualitative and quantitative data were then used to analyze for trends of strategies adopted by ANCCA members and other Asian cancer centers.

Questions were distributed into 6 major categories: impact at the national and at the institutional level; hospital 
preparedness; strategies in place or countermeasures; triage; zoning, and repurposing. Survey topics also included the impact of the pandemic on cancer treatment and cancer care, such as distancing measures, online systems and quality of life (QOL) management. The area of clinical trial was also included for cancer centers running clinical trials before the pandemic to understand the challenges the centers experienced in conducting clinical trials (including those related to COVID-19). The specific aspect of the financial impact of COVID-19 on each institution was also ascertained from all participating members.

Quantitative and qualitative results were analyzed and sorted to allow most meaningful comparison among cancer centers. The contribution of specialists with specific knowledge and expertise from a wide range of departments, including infection control, human resources, finances, and oncology field played an essential role in extracting in-depth information on challenges and ways of addressing the pandemic.

Thirteen ANCCA members and 2 non-ANCCAAsian major cancer centers responded to the voluntary survey, providing thorough insight on the impact of the pandemic, their countermeasures as well as short- and long-term strategies. Response collection occurred between 22-May 2020 and 2-June 2020 for ANCCA members and between 8-June 2020 and 14-June 2020 for other cancer centers in Asia, representing in total centers from 15 countries in the region. Subsequent direct interviews of specialists were conducted to obtain additional answers to open-ended questions that required for input as assessed during the survey analysis.

\section{Results}

\section{Pandemic in Asia: Overall status}

Among participating countries, the emergence of COVID-19 varied in magnitude and with time, reflecting the different timing of each government's decision to declare COVID-19 as national emergency (Figure 1). Two trends could be extracted from WHO [8] data comparing COVID-19 weekly incidence of participating countries as of 19-June 2020 (cut-off date) (Figure 1). The first was based on the number of weekly cases, segregating countries into four categories: "high" incidence $(>20,000$ weekly cases at peak); "higher middle" (between 4,000 and 8,000 cases weekly); "lower middle" (between 500 and 3,000 cases weekly at peak); and "low" (below 100 cases weekly at peak).

The second trend observed could also be classified in 3 different patterns: one single peak observed (per time of peak occurrence: China, Korea, Thailand, and Japan, seemingly having overcome the first wave of COVID-19); one peak followed by less prominent decrease (per time of first peak occurrence: Turkey and Singapore still struggling with rising curve); and a third group of countries with later start, a peak that did not reach at cut-off date (per time of occurrence start: Indonesia, India, Pakistan, and Nepal currently facing an ostentatious growth in the number of COVID-19 patients). The second trend was not applicable for countries with low COVID-19 incidence (i.e. Mongolia, Myanmar and Vietnam). The course of COVID-19 pandemic in each country (Figure 1) as well the actual encounter of COVID-19 patients at the cancer centers (Table 2) define the context and circumstances in which each institution took countermeasures to re-organize the delivery of cancer care while going through the pandemic.

\section{Regional leadership and strategies in place or implemented (including staff management)}

Despite the unpredictability of the pandemic, most participating cancer center adapted with immediate actions, partly due to availability of infection control measures and management practices, with 13 (87\%) cancer centers confirmed the existence of a specific infection control dedicated department in place, and 8 (53\%) confirmed the presence of dedicated staff. As a concrete action plan, most centers developed or updated guidelines or contingency measures in response to the pandemic. Eleven $(73 \%)$ centers developed or updated guidelines related to infection management as countermeasures to the pandemic. NCC-Singapore's programs are worth highlighting: high level of preparedness through the existence of the Disease Outbreak Response (DORS) taskforce, regular review of its operational manual according to national and international guidelines, as well as conducting pandemic response exercises within the campus. Two other concrete examples are from NCC-Korea with a system termed Drug Utilization Review (DUR) which allows the legal access of people's overseas travel history, as well as a screening processes (with instructions on screening clinics and booths at every entrance and every visitor) in place; and Myanmar-YGH's new guidelines for the use of blood and blood products.

In addition, as a response to the pandemic, 11 (73\%) centers took prompt and sustained educational initiatives directed at healthcare professionals and cancer patients, showing leadership in the cancer field in the Asia region with an obligation for educating the staff and public. India-TMC and NCC-Indonesia started regular webinars for healthcare professionals on 21-March 2020 and 22-April 2020 respectively [9-10]. Pakistan-SKCC launched a resource library and conducted information sharing sessions for healthcare providers starting from February 2020 [11] and published a COVID-19 guideline on 10-April 2020 [12]. NCC-Vietnam organized a weekly online consultation program ("Things to know for cancer patients during the COVID-19 pandemic"), as of 14-April 2020 [13]. NCC-China enhanced the health education for cancer patients and the public on personal protection measures and principles of cancer care during the pandemic. In Korea, the Korean Cancer Society and NCC-Korea made a press release on 29-April 2020 on the "Recommendations for cancer patients based on COVID-19 situation" [14].

As another evidence of regional leadership, 8 cancer centers $(53 \%$, India-TMC, NCC-Japan, NCC-Vietnam, Iran-TCI, Myanmar-YGH, Nepal-KCC and Pakistan- 


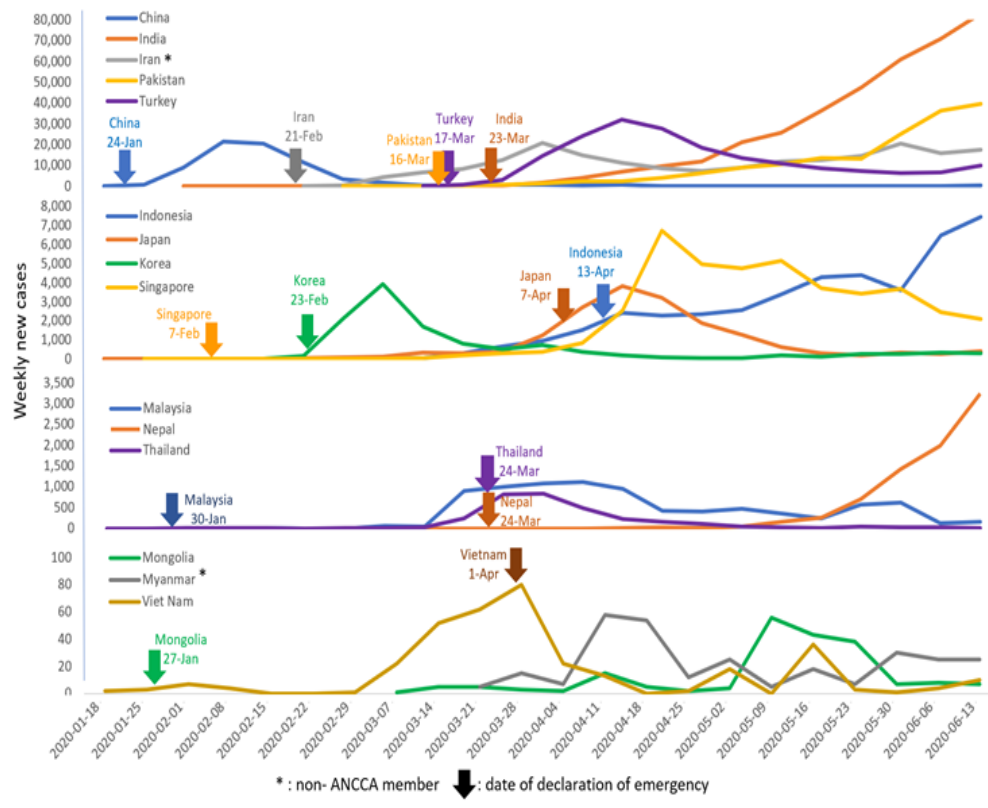

Figure 1. Transition of COVID-19 Case Based on WHO Data among Responders and Date of National Declaration of Emergency

SKCC) actively participated by contributing their eminent speakers to share their experience and expertise in virtual international meetings and symposium to combat COVID-19 for the benefit of other institutions or countries.

Staff management (including social distancing) was also a key focus of most centers, with respectively $9(60 \%)$ and $11(73 \%)$ centers implementing "working from home" and "virtual meetings" (Table 1). Decrease of staff was the norm, while increase of staff was also observed, partly due to staff re-allocation related to COVID-19 preparedness and management of triage; pre-screening; screening activities; as well as the treatment of COVID-19 patients, in about half the respondents (7 responders (54\%)).

It is noteworthy that NCC-Indonesia implemented workforce rearrangement strategy in order to protect staff (especially $>60$-year-old and with comorbidities) and to ensure successful implementation of social and physical distancing. India-TMC also took similar exemplary measures to address the psychological impact of the pandemic on healthcare workers through timely communication with all cadres of staff regarding preparedness, paid-leave for high-risk staff members (elderly people, people with co-morbidities or with immunosuppressive treatment and pregnant women); rotation of staff $\left(2 / 3^{\text {rd }}\right.$ on-site working and $1 / 3^{\text {rd }}$ working from home to ensure availability of enough numbers in case of mass exposure and quarantine); and arrangement of transport for staff during the lockdown. To secure proper care, Polymerase Chain Reaction (PCR) tests for staff suspected with COVID-19 was mandatory at 9 centers $(60 \%)$. NCC-Indonesia, NCI-Turkey-HOI, and Nepal-KCC implemented serologic/immunity test as a screening tool to select patients and healthcare workers who must take PCR-tests [15].
Triage (including guidelines), zoning, repurposing and material shortage - Hospital level

To combat the pandemic, all cancer centers adopted ad hoc short- and long-term measures from pre-screening to treatment or re-orientation of their cancer patients, while managing with the shortage of material (personal protective equipment (PPE), including masks, hand sanitizers, gowns, as well as oncology drugs, COVID-19 related drugs, other drugs, blood products, medical devices, and laboratory testing). Pre-screening measures included the travel history information system (NCC-China, NCC-Korea, NCC-Vietnam) and the massive COVID-19 screening and triage at the entrance (NCC-China, India-TMC, NCC-Korea, NCC-Indonesia and NCC-Singapore). As concrete examples, NCC-China closed all entrances except the main entrance, and NCC-Singapore established a fever screening clinic with COVID-19 swabbing capabilities and redirecting COVID-19 cancer outpatients to Singapore General Hospital. At NCC-Vietnam, early implementation of contingency plan and social distancing, as well as screening regulations (based on strategies taken by Central Government) eased the burden, facilitating COVID-19 prevention in the hospital.

More than half of responding centers ( 8 centers, $58 \%$ ) had actually encountered and mostly treated COVID-19 patients, while 6 centers (43\%) were COVID-19-free at the time of the survey (Table 2). The centers with major impact of COVID-19 were India-TMC and Pakistan-SKCC, dealing mainly with cancer patients with COVID-19, while NCC-Japan, NCI-Turkey-HOI, and Myanmar-YGH dealt mainly with COVID-19 patients from the general population. NCC-Japan was an outlier NCC, having to open a specific ward and treat 15 non-cancer patients as a response to the "special COVID-19 functioning hospital" by the Ministry of Health and Welfare from 14-April to 29-May 2020, reallocating up to 40 staff at the peak and 


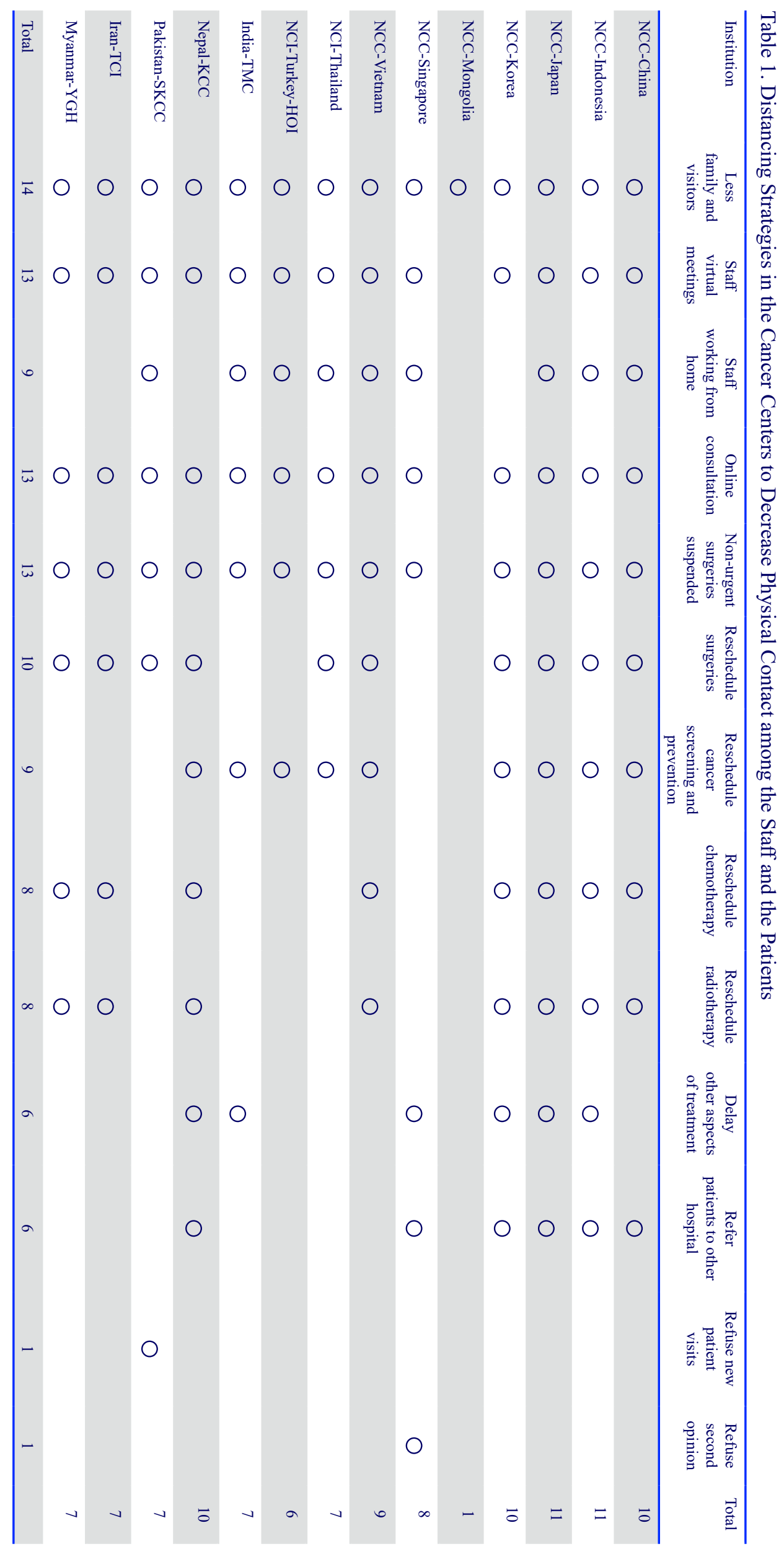


implementing 4 shifts to avoid contamination, all based on prior experience of infectious disease management. It is also noteworthy that Pakistan-SKCC contributed to the national effort against the coronavirus and made the strategic decision to enable free testing and treatment for COVID-19 cancer and non-cancer patients unable to afford it [16].

The actual material shortage status varied among centers, less impacting for centers not having encountered COVID-19 patients, except for NCC-Mongolia (experiencing shortage of oncology drugs and medical devices due to shipment delay) and Nepal-KCC (with shortage of PPE, cancer and non-cancer drugs as well medical devices and other equipment). For centers experiencing COVID-19 patients, a shortage of PPE, swabs, tubes for reagents, isolation gown, cancer and non-cancer drugs as well as of medical devices was noted at various levels depending on the centers. The highest impact of shortage was on PPE, and also reagents for PCR testing (NCC-Japan, NCC-Indonesia), and Rapid Detection Kit (RDT) (NCC-Indonesia). To overcome the pandemic, Pakistan-SKCC (the most affected institution) as well as India-TMC and NCC-Indonesia took initiatives such as accepting donations from philanthropic organisation or government while NCC-Singapore prevents the shortage of PPE through developing a strict PPE guideline for optimal protection of staff and patients. As a specific case, NCI-Turkey-HOI did not experience any specific shortage despite the high number of COVID-19 patients in the institution.

Patient care: impact on treatment and online systems Hospital level

Aiming to preserve high standards of care for patients with cancer, participating centers adapted to their healthcare environment and needs in different ways (Table 1). In addition to decreasing contact through exposure to family members and visitors, implemented by all centers $(100 \%)$, various aspects of cancer treatment were modified, with a non-negligible impact on both the institution and patients and their families. Worth noting is the postponement of non-urgent surgeries, rescheduled surgeries, cancer screening, chemotherapies or radiation therapies taken respectively by $13(93 \%)$, $10(71 \%), 9(64 \%), 8(57 \%)$ and $8(57 \%)$ centers, treatment modifications highlighted by several members as case-by-case decision based on prioritization. In order to minimise the impact on cancer treatment, respondents adopted different strategies, such as: for patients preparing to be admitted, NCC-China routinely recorded symptoms potentially associated with COVID-19, such as fever and cough through mandatory routine blood tests and high-resolution computed tomography scans of the lungs. India-TMC did not modify its treatment protocols except rescheduling the post-treatment follow-up and selecting less myelosuppressive chemotherapy for palliative

Table 2. Number of COVID-19 Positive Treated in the Cancer Centers and Zoning Plan for COVID-19 Patients

\begin{tabular}{|c|c|c|c|c|c|c|c|c|}
\hline & \multirow{2}{*}{ Institution } & \multirow{2}{*}{$\begin{array}{l}\text { \# COVID-19 } \\
\text { Positive cancer } \\
\text { patients (1) }\end{array}$} & \multirow{2}{*}{$\begin{array}{l}\text { (1) of which } \\
\% \text { treated at } \\
\text { institution }\end{array}$} & \multirow{2}{*}{$\begin{array}{l}\text { (1) of which \% } \\
\text { referred to } \\
\text { other hospital }\end{array}$} & \multirow{2}{*}{$\begin{array}{l}\text { \#Treated } \\
\text { general } \\
\text { population }\end{array}$} & \multicolumn{3}{|c|}{ Zoning plan for COVID-19 patients } \\
\hline & & & & & & $\begin{array}{c}\text { Single } \\
\text { entry / exit }\end{array}$ & $\begin{array}{l}\text { Separate } \\
\text { entry / exit }\end{array}$ & $\begin{array}{c}\text { Dedicated } \\
\text { ward }\end{array}$ \\
\hline \multirow[t]{6}{*}{$\begin{array}{l}\text { No encounter with } \\
\text { COVID-19 patients }\end{array}$} & NCC-China & 0 & N/A & $\mathrm{N} / \mathrm{A}$ & 0 & & $\mathrm{O}$ & O \\
\hline & NCC-Korea & 0 & N/A & N/A & 0 & & O & $\mathrm{O}$ \\
\hline & NCC-Mongolia & 0 & N/A & $\mathrm{N} / \mathrm{A}$ & 0 & & & O \\
\hline & NCC-Vietnam & 0 & N/A & $\mathrm{N} / \mathrm{A}$ & 0 & & O & \\
\hline & NCI-Thailand & 0 & N/A & $\mathrm{N} / \mathrm{A}$ & 0 & O & & O \\
\hline & Nepal-KCC & 0 & $\mathrm{~N} / \mathrm{A}$ & $\mathrm{N} / \mathrm{A}$ & 0 & & $\bigcirc$ & \\
\hline \multirow[t]{8}{*}{$\begin{array}{l}\text { Encounter with } \\
\text { COVID-19 patient (s) }\end{array}$} & NCC-Indonesia & $\begin{array}{c}5 \\
(100 \%)\end{array}$ & $\begin{array}{c}4 \\
(80 \%)\end{array}$ & $\begin{array}{c}1 \\
(20 \%)\end{array}$ & 0 & & $\bigcirc$ & $\bigcirc$ \\
\hline & NCC-Japan & $\begin{array}{c}2 \\
(100 \%)\end{array}$ & $\begin{array}{c}1 \\
(50 \%)\end{array}$ & $\begin{array}{c}1 \\
(50 \%)\end{array}$ & 15 & & $\bigcirc$ & $\mathrm{O}$ \\
\hline & NCC-Singapore & $\begin{array}{c}3 \\
(100 \%)\end{array}$ & $\begin{array}{c}2 \\
(67 \%)\end{array}$ & $\begin{array}{c}1 \\
(33 \%)\end{array}$ & 0 & 0 & & \\
\hline & NCI-Malaysia & $\begin{array}{c}1 \\
(100 \%)\end{array}$ & $\begin{array}{c}0 \\
(0 \%)\end{array}$ & $\begin{array}{c}1 \\
(100 \%)\end{array}$ & 0 & 0 & & \\
\hline & NCI-Turkey-HOI & $\begin{array}{c}7 \\
(100 \%)\end{array}$ & $\begin{array}{c}7 \\
(100 \%)\end{array}$ & $\begin{array}{c}0 \\
(0 \%)\end{array}$ & 350 & & & O \\
\hline & India-TMC & $\begin{array}{c}314 \\
(100 \%)\end{array}$ & $\begin{array}{c}264 \\
(84 \%)\end{array}$ & $\begin{array}{c}50 \\
(16 \%)\end{array}$ & 0 & O & & O \\
\hline & Myanmar-YGH & $\begin{array}{c}1 \\
(100 \%)\end{array}$ & $\begin{array}{c}1 \\
(100 \%)\end{array}$ & $\begin{array}{c}0 \\
(0 \%)\end{array}$ & 10 & & $\bigcirc$ & \\
\hline & Pakistan-SKCC & $\begin{array}{c}231 \\
(100 \%)\end{array}$ & $\begin{array}{c}67 \\
(29 \%)\end{array}$ & $\begin{array}{c}164 \\
(71 \%)\end{array}$ & 21 & & 0 & 0 \\
\hline
\end{tabular}


Table 3. Proportion and Types of Online Consultations at each Cancer Centers before and During the Pandemic

\begin{tabular}{|c|c|c|c|c|c|c|c|c|}
\hline \multirow[t]{2}{*}{ Institution } & \multirow{2}{*}{$\begin{array}{l}\text { Prior system } \\
\text { in place } \\
\text { for online } \\
\text { consultation }\end{array}$} & \multirow{2}{*}{$\begin{array}{l}\% \text { Online } \\
\text { consultation } \\
\text { prior to } \\
\text { pandemic }\end{array}$} & \multirow{2}{*}{$\begin{array}{c}\% \text { Online } \\
\text { consultation } \\
\text { during pandemic }\end{array}$} & \multicolumn{4}{|c|}{ Types of online consultation } & \multirow[t]{2}{*}{ Notes } \\
\hline & & & & Telephone & Video & Chat-based & E-mails & \\
\hline NCC-China & $\bigcirc$ & $5 \%$ & $70 \%$ & & & $\Omega$ & & $\begin{array}{l}\text { System in place, free of charge, } \\
\text { chat-based system on NCC } \\
\text { website }\end{array}$ \\
\hline NCC-Indonesia & & $0 \%$ & $10 \%$ & & $C$ & & & $\begin{array}{l}\text { Online consultation available but } \\
\text { outside of the scope of insurance } \\
\text { coverage }\end{array}$ \\
\hline NCC-Japan & & $0 \%$ & $8 \%$ & & & & & $\begin{array}{l}\text { Approval of online consultation } \\
\text { by MHLW on 1-Apr, allowing } \\
\text { patients to pick up their drugs at } \\
\text { pharmacies closed to their house }\end{array}$ \\
\hline NCC-Korea & & $0 \%$ & $3 \%$ & & & & & $\begin{array}{l}\text { Online (telephone) consultation } \\
\text { legalized on } 24-\mathrm{Feb}\end{array}$ \\
\hline NCC-Mongolia & $\bigcirc$ & $0 \%$ & $0 \%$ & & & & & $\begin{array}{l}\text { National insurance scheme } \\
\text { system in place for online cons } \\
\text { ultation, not applied yet due to no } \\
\text { COVID-19 transmission }\end{array}$ \\
\hline NCC-Singapore & $\bigcirc$ & $0 \%$ & $10 \%$ & & & & & $\begin{array}{l}\text { Secure system recently developed } \\
\text { for consultation and charging }\end{array}$ \\
\hline NCC-Vietnam & & $0 \%$ & $90 \%$ & & $\bigcirc$ & & & $\begin{array}{l}\text { Common unofficial practice of } \\
\text { telephone consultation between } \\
\text { patient and physician, not paid } \\
\text { therefore not recorded }\end{array}$ \\
\hline NCI-Thailand & & $0 \%$ & $5 \%$ & J & $\bigcirc$ & $\bigcirc$ & & \\
\hline NCI-Turkey-HOI & & $0 \%$ & $25 \%$ & O & & & & \\
\hline India-TMC & & $10 \%$ & $30 \%$ & & & & 0 & \\
\hline Nepal-KCC & & $60 \%$ & $80 \%$ & $\bigcirc$ & & & 0 & \\
\hline Pakistan-SKCC & $\bigcirc$ & $0 \%$ & $60 \%$ & & $\Omega$ & & & $\begin{array}{l}\text { Online credit card mobile billing } \\
\text { application }\end{array}$ \\
\hline Iran-TCI & & $20 \%$ & $40 \%$ & 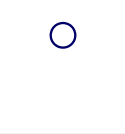 & 0 & & & $\begin{array}{l}\text { Online consultation applied } \\
\text { only at palliative care services, } \\
\text { through the use of personal phone } \\
\text { number }\end{array}$ \\
\hline Myanmar-YGH & & $30 \%$ & $50 \%$ & & & $\Omega$ & & $\begin{array}{l}\text { Booking ahead, Viber group, } \\
\text { Facebook page }\end{array}$ \\
\hline
\end{tabular}

indication; while NCC-Indonesia and NCC-Vietnam rescheduled suitable treatments making sure not to compromise the treatment objectives. Two exceptional cases were NCI-Turkey-HOI, with no modification in cancer treatment, and NCC-Mongolia, with zero local transmission as of 22-May 2020 (time of filling the survey), which only restricted the number of family members and visitors.

Focusing on the "telemedicine" aspect, 13 centers (93\% of participants) implemented online consultation in various ways (Table 3 ). NCC-Vietnam made the most significant change: from zero before to $90 \%$ during the pandemic. NCC-China, India-TMC, Nepal-KCC, Iran-TCI, and Myanmar-YGH had already implemented the online consultation system prior to the pandemic, which allowed for a smoother implementation. In China, the national health and insurance system in place allowed cancer patients from all over China to get free access to online free-of-charge consultations including instructions on taking medication and cancer-related symptoms management. In Japan, the Ministry of Health and Welfare approved Emergency Countermeasures for COVID-19 on 7-April 2020 which allowed NCC-Japan to implement telemedicine [17], still in application at the time of this manuscript submission. Another fast shift was in NCC-Singapore's implementation of a secure system for consulting and charging.

On the quality of life perspective (Table 4), most centers took initiatives: NCC-Singapore allowed video-conferencing for patients and their families, as well as between medical teams and relatives to update on patient's conditions. NCC-Japan and NCI-Turkey-HOI, smoothened the prescription process to facilitate patients to obtain drugs through online consultation without the burden of an hospital visit. NCC-China, NCC-Vietnam and India-TMC undertook similar approaches to overcome COVID-19 impact on patient's wellbeing by providing food or nutrition support, psychosocial support, as well links with web-based support group meetings. NCC-Japan provided web-support, allowing home exercise for cancer 
Table 4. Initiatives Related to Quality of Life of the Patients

\begin{tabular}{|c|c|c|}
\hline \multirow[t]{2}{*}{ Institution } & \multicolumn{2}{|c|}{ Specific actions to maintain cancer patient quality of life } \\
\hline & Outpatient support & Inpatient support \\
\hline NCC-China & & $\begin{array}{l}\text { Education on the nutrition by nurses, physical activity and } \\
\text { psycho-oncology support for inpatients }\end{array}$ \\
\hline NCC-Indonesia & $\begin{array}{l}\text { 1. Provision of online consultation for palliative patients, } \\
\text { conducted by palliative doctor as alternative solution for home } \\
\text { care/visit that cannot be held during partial lockdown } \\
\text { 2. Provision of medicine refill through electronic prescription } \\
\text { following online consultation }\end{array}$ & $\begin{array}{l}\text { Psychology support for suspected or confirmed cases of COVID-19 } \\
\text { patients by clinical psychologist to facilitate patients' acceptance } \\
\text { on their illness, reduce patients' anxiety, and provide motivation to } \\
\text { improve patient's condition }\end{array}$ \\
\hline NCC-Japan & $\begin{array}{l}\text { 1. Information sharing about home exercise for physical } \\
\text { activity } \\
\text { 2. Prescriptions made available at local pharmacy after online } \\
\text { consultation with physician }\end{array}$ & \\
\hline NCC-Korea & $\begin{array}{l}\text { 1. Provision the home hospice visit service to the patients as } \\
\text { usual with medical staffs only (no volunteers, social welfare } \\
\text { workers, etc.) } \\
\text { 2. Maintain the highest sanitary conditions to the visitors by } \\
\text { applying strict infection control policy }\end{array}$ & $\begin{array}{l}\text { Maintaining the provision of palliative care service while } \\
\text { minimizing group meeting among patients and the number of } \\
\text { responsible staffs (e.g. excluding volunteers and maintaining only } \\
\text { medical staffs) }\end{array}$ \\
\hline NCC-Mongolia & No particular action needed to limited impact of COVID19 & $\begin{array}{l}\text { Introduction of dedicated hours and restricted access for the visitors } \\
\text { and family members at the hospital }\end{array}$ \\
\hline NCC-Singapore & $\begin{array}{l}\text { 1. Support to inpatient medical teams by palliative physician } \\
\text { 2. Video consultation for community care team for outpatients } \\
\text { for management of pain and other quality of life issues }\end{array}$ & $\begin{array}{l}\text { 1. Video conferencing for patients to stay in contact with their } \\
\text { family } \\
\text { 2. Communication between medical team and relatives to update } \\
\text { conditions as visitors are not allowed in the wards }\end{array}$ \\
\hline NCC-Vietnam & $\begin{array}{l}\text { Tele-consultation open session on the hospital website and } \\
\text { Facebook about nutrition and psycho-oncology support for } \\
\text { patients }\end{array}$ & \\
\hline NCI-Turkey-HOI & No need for prescription and coming to hospitals & \\
\hline India-TMC & $\begin{array}{l}\text { 1. Provision of food and accommodation } \\
\text { 2. Travel arrangement } \\
\text { 3. Linking them with the volunteers for psychosocial support } \\
\text { 4. Support group meetings using platforms like zoom }\end{array}$ & $\begin{array}{l}\text { 1. Provision of food to the relatives } \\
\text { 2. Extending the stay for those who were outstation patients }\end{array}$ \\
\hline Nepal-KCC & $\begin{array}{l}\text { Provision of free vehicle facilities for cancer patients and hand } \\
\text { sanitizer to all }\end{array}$ & \\
\hline Pakistan-SKCC & $\begin{array}{l}\text { Everyday telephonic updates for relatives. Video calls between } \\
\text { patients and relatives }\end{array}$ & \\
\hline Iran-TCI & $\begin{array}{l}\text { Palliative care team (volunteers) in some region support } \\
\text { patients/ virtual consultation by palliative medicine specialist }\end{array}$ & Virtual tumor boards about difficult patients \\
\hline Myanmar-YGH & $\begin{array}{l}\text { Provision of bed allocation } 3 \text { feet apart/by marking waiting } \\
\text { area for social distancing, provision of hand washing facility, } \\
\text { restriction of patient attendance }\end{array}$ & $\begin{array}{l}\text { Provision of good nutrition support and palliative care for all } \\
\text { inpatients }\end{array}$ \\
\hline
\end{tabular}

patients.

\section{Clinical trials}

Research-wise, the pandemic also highly impacted 8 of the 9 centers $(89 \%)$ who were actively participating in clinical trials prior to the pandemic, with NCC-Vietnam as an exception, not much impacted due to short social distancing period and controlled outbreak in Vietnam. Most industry-led trials were delayed, with major impact on patient recruitment and visits on 7 centers $(78 \%)$, and on the overall timeline for 6 centers (67\%) (Table 5).

Relevant actions and countermeasures included: rapid identification of life-saving clinical trials for immediate approval to continue; deployment of clinical trial coordinators to triage and screening when patient recruitment was reduced (NCC-Singapore); telephone-call based follow-up for trial patients and sending drugs by courier services (India-TMC). By contrast to industry-lead clinical trials, NCC-Japan reported that the impact on investigator-led clinical trials was limited.

Acting as Asian leaders in their field, several ANCCA members also actively contributed to knowledge on COVID-19: NCC-Singapore's collaboration on a clinical trial on Virus specific T cells for COVID-19, India-TMC evaluating cancer outcomes in patients with COVID-19, NCC-Japan and Pakistan-SKCC respectively participating in a nationwide Avigan observational study and a WHO COVID-19 vaccine clinical trial.

Impact on NCCs'departments (including manpower and financial impact)

National Cancer Centers and Institutions from ANCCA are established as leading cancer centers in the region, hosting a broad range of cancer related services to maintain a comprehensive cancer care, cancer control activities, and research on cancer. Clinical and education services and research activities are core activities for all participating centers, besides the other cancer-related departments as depicted in Table 6. All participating centers, even the 6 centers which did not experience COVID-19 patients, were affected by the pandemic. Most highly impacted departments were the hospitals (all centers impacted, 
Table 5. Impact of COVID-19 Pandemic on Clinical Trials

\begin{tabular}{|c|c|c|c|c|c|c|}
\hline Institution & $\begin{array}{l}\text { Patient Recruitment } \\
\text { or Enrolment }\end{array}$ & $\begin{array}{c}\text { Providing } \\
\text { investigational } \\
\text { product to patients }\end{array}$ & Patients' visits & $\begin{array}{l}\text { Overall } \\
\text { quality }\end{array}$ & $\begin{array}{l}\text { Overall } \\
\text { completion } \\
\text { timeline }\end{array}$ & $\begin{array}{l}\text { Participation to new clinical trial related to } \\
\text { COVID-19 }\end{array}$ \\
\hline NCC-China & $\bigcirc$ & $\bigcirc$ & $\bigcirc$ & & $\bigcirc$ & N/A \\
\hline NCC-Japan & O & & O & & O & $\begin{array}{l}\text { Avigan observational study. } 14 \text { out of } 15 \\
\text { COVID-19 patients at NCC were enrolled. } \\
\text { This study is a nation-wide study }\end{array}$ \\
\hline NCC-Korea & O & & O & & O & N/A \\
\hline NCC-Singapore & $\bigcirc$ & 0 & 0 & & $\bigcirc$ & $\begin{array}{l}\text { Collaboration on clinical trial on Virus } \\
\text { specific T cells for COVID-19 }\end{array}$ \\
\hline NCC-Vietnam & & & & & & N/A \\
\hline NCI-Turkey-HOI & O & & & & & N/A \\
\hline India-TMC & $\bigcirc$ & $\bigcirc$ & $\bigcirc$ & & O & $\begin{array}{l}\text { Cancer outcomes in patients with } \\
\text { COVID-19 ongoing }\end{array}$ \\
\hline Pakistan-SKCC & O & & O & & & WHO COVID-19 Vaccine Trial \\
\hline Iran-TCI & & & $\bigcirc$ & $\bigcirc$ & $\bigcirc$ & N/A \\
\hline
\end{tabular}

N/A, Not Applicable

respectively highly impacted and impacted somehow by $8(57 \%)$ and $6(43 \%)$ centers), education services and cancer screening and prevention (respectively 10 centers (71\%) and 7 centers $(50 \%)$ had to shut down or were highly impacted). In NCC-Vietnam, the social distancing regulations, even though for a limited period of time, created a huge burden on internal resource requirement and operational coordination, with a drastic increase of patients (new and existing) at the imaging diagnostic department, resulting in subsequent increase of workload for the whole department following the lifting of social distancing measures.

Financial consequences in most departments caused by the pandemic were significant, estimated to be around $30 \%$ loss in comparison with the previous year, depending on the institution. Countermeasures were limited or non-existent for most cancer centers at the time of completion of the survey. COVID-19 related expenses were diverse, including reduction of outpatient and inpatient visits, staff and medical equipment shortage after complete or partial lockdown declared in all participating countries, independently from the actual occurrence of cases in the country or the institution. Striking examples are NCC-Vietnam and NCC-Mongolia which were highly financially impacted despite low number of cases in the country. NCC-Vietnam experiencing a $30 \%$ financial loss due to triage and reduction of patient visits in addition to the increased budget spent on extra-hours to screen staff and visitors, to quarantine suspected cases and other related measures. Another costly investment worth pointing out was the new fever and triage area in NCCSingapore, and cost related to the increased lab capacity

Table 6. Impact of COVID-19 on each Institution

\begin{tabular}{|c|c|c|c|c|c|c|c|c|}
\hline Institution & Hospital & $\begin{array}{l}\text { Cancer Screening } \\
\text { and Prevention }\end{array}$ & $\begin{array}{l}\text { Research } \\
\text { Institute }\end{array}$ & $\begin{array}{c}\text { National } \\
\text { Cancer Control } \\
\text { Department }\end{array}$ & $\begin{array}{l}\text { Public } \\
\text { health }\end{array}$ & $\begin{array}{c}\text { Educational } \\
\text { services }\end{array}$ & $\begin{array}{c}\text { Central Laboratories / } \\
\text { PCR machines }\end{array}$ & $\begin{array}{c}\text { Overall } \\
\text { impact on } \\
\text { workforce }\end{array}$ \\
\hline NCC-China & $* *$ & $* *$ & $* * *$ & * & N/A & $* *$ & $* * *$ & - \\
\hline NCC-Indonesia & $* *$ & $* * *$ & - & N/A & N/A & $* * *$ & $* *$ & $\downarrow$ \\
\hline NCC-Japan & $* *$ & $* * *$ & $*$ & * & $*$ & $* * *$ & $* *$ & $\downarrow$ \\
\hline NCC-Korea & $*$ & $*$ & $*$ & $*$ & $* *$ & $* *$ & $*$ & $\downarrow$ \\
\hline NCC-Mongolia & * & $*$ & - & - & - & $* *$ & - & - \\
\hline NCC-Singapore & $* *$ & $*$ & $* * *$ & N/A & N/A & $* *$ & $* *$ & $\uparrow$ \\
\hline NCC-Vietnam & * & $*$ & - & N/A & $* *$ & $*$ & - & $\downarrow$ \\
\hline NCI-Thailand & $*$ & $* *$ & - & * & $* *$ & $*$ & - & $\uparrow$ \\
\hline NCI-Turkey-HOI & $*$ & $*$ & $*$ & $*$ & $*$ & $* *$ & - & $\downarrow$ \\
\hline India-TMC & $*$ & $* * *$ & $* *$ & $* *$ & $* * *$ & $*$ & - & $\downarrow$ \\
\hline Nepal-KCC & $*$ & $* *$ & $*$ & $*$ & - & - & - & $\downarrow$ \\
\hline Pakistan-SKCC & $* *$ & N/A & - & - & $\mathrm{N} / \mathrm{A}$ & $* *$ & - & - \\
\hline Iran-TCI & $* *$ & $* *$ & $*$ & $* *$ & $* *$ & $* *$ & $* *$ & $\downarrow$ \\
\hline Myanmar-YGH & $*$ & $*$ & $*$ & $*$ & $*$ & $* *$ & $*$ & $\downarrow$ \\
\hline
\end{tabular}

*** Had to shut down; ** Highly impacted; * Impacted somehow; -No change; $\uparrow$ Increase; $\downarrow$ Decrease; N/ANot applicable 


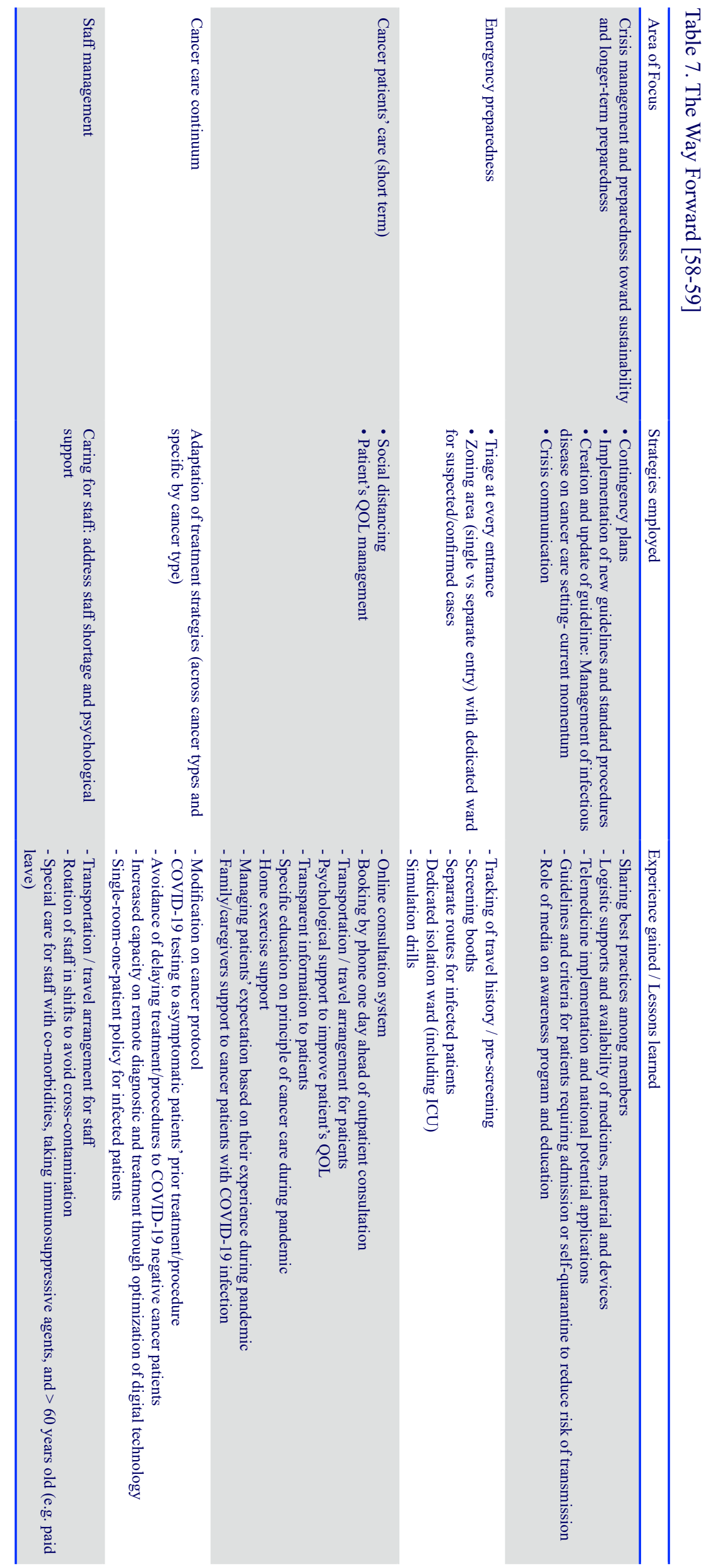


Appendix 1. Cumulative COVID-19 Cases and Deaths (13-July 2020)

\begin{tabular}{lcc}
\hline Country & Cumulative cases & Cumulative deaths \\
\hline India & 878,254 & 23,174 \\
\hline Iran & 257,303 & 12,829 \\
\hline Turkey & 212,993 & 5,363 \\
\hline Pakistan & 251,625 & 5,266 \\
\hline China & 85,568 & 4,648 \\
\hline Indonesia & 75,699 & 3,606 \\
\hline Japan & 21,868 & 982 \\
\hline Korea & 13,479 & 289 \\
\hline Malaysia & 8,718 & 122 \\
\hline Thailand & 3,220 & 58 \\
\hline Nepal & 16,801 & 38 \\
\hline Singapore & 45,961 & 26 \\
\hline Myanmar & 331 & 6 \\
\hline Mongolia & 230 & 0 \\
\hline Viet Nam & 372 & 0 \\
\hline
\end{tabular}

in NCC-Indonesia (which was appointed on 15-April 2020 by the Regional government to provide PCR tests for COVID-19).

\section{Discussion}

\section{NCC Leadership and strategies}

National Cancer Centers around the world have the responsibility to balance the risk from delay in cancer diagnosis or treatment against the potential risk of COVID-19 exposure, mitigate the risk of disruptions to cancer care delivery during implementation of social distancing strategy, and manage the proper allocation of limited health care resources. Outbreaks of infection etiology, particularly those caused by a novel virus with no known treatment, may result in the interruption of medical care provided to patients with cancer and put them at risk for undertreatment in addition to the risk of being exposed to infection, which collectively could be a life-threatening event for patients with cancer [18].

ANCCA members have established a roadmap at the end of 2019 [7] with short-, mid-, and long-term goals to halt cancer increase and mortality rates in Asian countries by 2030 . The pandemic, through its dramatic impact on society, and even further on cancer care, has opened doors to new collaboration and goals not originally specified. Such pandemic challenge faced by each and every country in the region has allowed ANCCA members to increase the speed and focus the goal of collaboration to decrease the impact of the pandemic on one of the most affected population: cancer patients and healthcare professionals. Shortly after the start of the pandemic, on 22-April 2020, the presidents of 3 NCCs (NCC-China, NCC-Japan and NCC-Korea) virtually gathered to share latest updates, followed by a virtual meeting attended by most members on 20-May 2020, to promote information sharing among ANCCA members through a survey addressed to each institution representative.
Managing cancer care through a pandemic was not new for 10 participating cancer centers $(67 \%)$ which experienced one or two major coronavirus outbreaks in the region: Severe Acute Respiratory Syndrome (SARS) with a 2003 and Middle East Respiratory Syndrome (MERS), with a 2012 outbreak that have allowed several Asian countries to prepare for the pandemic, from a governmental as well as institution level management of the pandemic [19]. The participating countries of this study were respectively China, India, Indonesia, Korea, Malaysia, Mongolia, Thailand and Vietnam for SARS and Korea, Malaysia, Iran and Turkey for MERS [20] with Korea and Malaysia experiencing their third encounter this time since coronavirus in 2002.

The survey outcomes included the establishment of an infection control department and/or dedicated staff, which turned out to be in place prior to the pandemic for respectively 13 centers $(87 \%)$ and 8 centers $(53 \%)$, allowing the distribution of fast and relevant information to the community (healthcare workers, as well as patients) that are key to contribute to national, regional and international efforts to decrease the impact of the pandemic on cancer care.

The results of this study include lessons learned through very stringent actions for NCC-China and NCCKorea, both tracking the travel history and symptoms of all individuals as well as performing a thorough screening at entrance of all employees.

\section{Caring for staff strategies}

Cancer care providers are at increased risk for coronavirus infection as chances of acquiring infection at workplace are high. Previous experiences of SARS and MERS outbreaks had shown that the rate of Coronavirus transmission among healthcare workers were significant, accounting for $21,07 \%$ [21] and 19,1\% [22-23] of confirmed cases, respectively. Current data on COVID-19 case among healthcare providers are incomplete and very dynamic. However several studies have reported a high rate of COVID-19 transmission among healthcare workers since the onset of the outbreak [23-25]. This situation has led to substantial decrease of available staff due to selfisolation (staff was suspected of COVID-19 or household member developed symptoms).

The pressure of working under pandemic circumstances was augmented by staff's anxiety of the risk of personal contamination and extended work hours [25]. Having contact with confirmed cases of COVID-19 demonstrated as significant factors of high level of distress, experienced by $29-35 \%$ healthcare workers delivering care to SARS patients [26] and $26 \%$ of doctors involved in MERS care [27]. Past experience provided lessons that healthcare management team should put attention on staff's need of logistic and psychological support [23]. In NCCs of the participating countries, staff protection is one key focus of COVID-19 related strategies, including the implementation of staff virtual meeting and working from home policies to ensure social distancing approach; modification on treatment regimens and rescheduling of non-urgent treatment to reduce hospital 
visits, and psychological support for staff dealing with suspected or confirmed COVID-19 cases.

\section{Impact on patient care}

Cancer center efforts to continue its operations and ensure the safety to resume elective procedures have been guided by standards published by international oncology associations, particularly ESMO, ASCO, NCCN, and American College of Surgeons. Patients prioritization and modification of cancer treatment protocols were implemented to reduce hospital visits and ensure the implementation of social distancing measures in order to minimize the risk of SARS-CoV2 transmission. Similar approaches have been taken by cancer centers worldwide, for instance oncology institutions under the legal entity of Cancer Core Europe (CCE) [28] and comprehensive cancer centers in US [29-31]. The strategy was effective to reduce the overall number of cancer patients admitted by $70-80 \%$ of the normal influx [28] and decrease the on-treatment patient volume (OPTV) by $25 \%$ in anticipation of the expected local COVID-19 peak [29].

The extent of social-distancing strategies implemented by NCCs are determined by government approaches to control pandemic at the national level. The populationlevel physical distancing measures and movement restrictions, often referred as "shut down" and "lock downs" were introduced in many countries, especially where community transition has led to outbreaks with near exponential growth [32]. Two different approaches to control COVID-19, namely suppression and mitigation were introduced and implemented in each country with varying extent. Suppression strategies aim to reach nearly complete suppression (reverse the epidemic spread to reproduction number $(\mathrm{R})<1$ and establish population immunity once a vaccine becomes available) [28,33], while mitigation strategies aim to keep COVID-19 incidence consistently at the maximum levels acceptable in order to prevent overwhelming the healthcare systems (establishing population immunity with or without a vaccine) [28]. China, Singapore, and South Korea have demonstrated an example of suppression strategy [28-34], whereas India [35] and Indonesia [36] have been employing a mitigation strategy. Complete suppression is the ideal strategy in cancer care setting, though the potential socio-economic impact of closing down the society have led countries to employ a mitigation approach over suppression strategies.

Strict social-distancing strategies have led to psychological issues in cancer patients due to the uncertainty of treatment continuation. As leading cancer centers in Asia, participating NCCs in our study provide care to cancer patients throughout the countries and serve as main referral cancer hospital in the region [37]. During the pandemic, access to healthcare is difficult in the current restrictive mobilization state and travel limitation [35]. Furthermore, many patients have been fearful of exposing themselves to the risk of infection and have been more reluctant to present to healthcare services. This situation affects the mental health of the patients and their families in addition to anxiety caused by cancer diagnosis and treatment [37]. The ANCCA members and participating countries have implemented impactful initiatives including travel and vehicle arrangement, employing telemedicine to provide psycho-oncology support, cancer education, nutrition support, and video recording for home-exercise. Automated medication refill and delivery have been also provided to ensure treatment continuity (Table 4). As supported from the literature, communication using digital technology can be adopted as a key strategy to continue delivery of cancer care while protecting vulnerable oncology patients and health care workers [38-39]. Telemedicine is also tool to empower patients and caregivers, therefore alleviate their social burden and improve quality of life [37].

The COVID-19 pandemic is rapidly transforming the medical care system and the use of industry 4.0 technologies has the potential to fulfil customised requirements during the crisis [40]. Several implementations such as telemedicine, utilization of travel databases for adequate screening, as well as virtual meetings admittedly are effective approaches to avoid potential risk of COVID-19 exposure. Going forward, further application of technologies, for instance digital imaging, remote medication supply, the use of machine learning and artificial intelligence for autonomous robot for examination, and the use of virtual reality environment for training and education purposes are transformational windows of opportunity for safer oncology care and training delivery [40]. Virtual care delivery should be appropriately documented to facilitate billing [41]. National health coverage and commercial medical insurance should reconsider to revise their payment policy and provide reimbursement for telemedicine activities in response to pandemic [42]. Currently, telemedicine is more of a use to follow up cases and is not adequate for newly diagnosed of cancer or patients under evaluation. There is still a need of face-to-face consultation for optimal evaluation of new patients. Delaying or postponing cancer treatment due presumed increased risk of infection with COVID-19 is a matter of debate and dilemma [37].

Several studies which demonstrated that cancer patients are more vulnerable to COVID-19 complications have encouraged physicians to withhold or postpone cancer treatment during the epidemic [43-47]. The NCCs have been applying strict social distancing measures that aim to decrease hospital visits and elective procedure. Furthermore, cancer control measures have been temporarily put on hold as NCCs' effort to minimize potential exposure of cancer patients to SARS-CoV-2. Our study showed that cancer control activities, in particular cancer screening and prevention have been impacted in varying degrees. Cancer screening has also been suspended, similarly to several countries in Europe [48], UK [49], US [50-51] following a call from the government to prioritize on coronavirus-related treatments. Halting cancer screening procedures will lead to more advanced stage at diagnosis, and in the future, higher economic burden of a delayed diagnosis of cancer will be loaded on public health economy [52-54]. The NCCs need to prepare for the expected increase of patients when government 
decide to loosen the social distancing measure. Huge workload of patient influx in the case of imaging diagnostic on NCC Vietnam is an example of future burden due to delayed diagnosis and cancer treatment that led to risk of exhausted health system.

In the clinical perspective, the paucity of solid evidence on the benefit of treatment modification or interruption should led to careful decision by oncologists and individualized for every patient [25]. Recent studies by Kuderer et al. [55] and Lee et al. [56] argue that treatment delays would significantly cause more harm to cancer patients [52]. In both studies, risk of death of cancer patients who had confirmed coronavirus infection was significantly associated with age, male sex, former smokers, associated comorbidities, active cancer and poor performance score; but not with administration of immunotherapy, chemotherapy, radiation therapy or targeted therapy within 4 weeks of detection of SARS-CoV-2. These evidences clearly urge the need to facilitate the cancer continuum and government decision to re-open the society.

\section{Cancer research and clinical trials}

The pandemic has affected clinical care in a broad range of settings, disrupting all aspects of clinical care, including cancer clinical trials. Numerous challenges with conducting clinical trials highlight opportunities to be evaluated and applied as proposed in the US [57] and also in the Asian region. The experience of the nine centers $(60 \%)$ actively conducting clinical trials provides additional insight on the dramatic impact of the pandemic in Asia, particularly, on patient recruitment and patients' visits for sponsored clinical trials, while investigatorinitiated clinical trials were less impacted. Going forward, the restart of clinical studies, as well as the implementation of COVID-19 related clinical trials are likely to create a significant delay and financial burden on the conduct of clinical trials. A new norm will have to be applied around the world to catch up with such huge impact. Unnecessary visits, and other activities set in study protocols can be removed after discussion among pharmaceutical companies, healthcare professionals and patients, to minimize the burden on patients while optimizing well balanced clinical trials.

On the other front, epidemiological and registry research on the impact of COVID-19 on cancer care in national cancer institutions will be key to address issues, not only within clinical trials, but to cover the full scope of cancer care.

\section{Way Forward/Preparing for the future}

The COVID-19 pandemic is likely to disrupt health system in lasting ways. Estimating the extent and severity of novel disease outbreaks is dependent on aggressiveness, accessibility and availability of specific testing. Although there could be differences in population demographics and access to healthcare, COVID-19 death rates (as shown in Appendix 1) could be more reflective of the true incidence and impact of the current pandemic. The current strategies taken by NCCs are likely to evolve over time, depending on the stage and width of the pandemic. The priorities are to focus on maintaining cancer care delivery while protecting both patients and health care workers from the risk of COVID-19 transmission. With some countries having loosened up the population-level physical distancing measures and movement restrictions (as of 8-July 2020, the time of this writing) and preparing for their "new normal", NCCs in Asia have to continuously monitor and evaluate the effectiveness of their mitigation strategy (Table 7). ANCCA will keep playing the role of a think-tank, gathering brains to share expertise, lessons learned and allow win/win scenarios among all participating cancer centers (Table 7).

\section{Acknowledgements}

\section{None}

\section{Statement conflict of Interest}

No potential conflict of interest was reported by the authors

\section{Funding Statement}

The authors thank the Japan National Cancer Center for Research and Development Fund (30-A-21) as well as the National Medical Research Council of Singapore for Research Centre Grant funding support.

\section{References}

1. World Health Organization. Rolling updates on coronavirus disease (COVID-19) World Health Organization. Available at: www.who.int/emergencies/diseases/novelcoronavirus-2019/events-as-they-happen. [Accessed 13 July 2020].

2. World Health Organization. Coronavirus disease (COVID-19) Situation Report-175. Available at: www.who.int/docs/ default-source/coronaviruse/situation-reports/20200713covid-19-sitrep-175.pdf?sfvrsn=d6acef25_2. [Accessed 13 July 2020.

3. World Health Organization. Coronavirus disease (COVID-19) Report of the WHO-China Joint Mission on Coronavirus Disease 2019 (COVID-19). Available at: www.who.int/docs/ default-source/coronaviruse/who-china-joint-mission-oncovid-19-final-report.pdf. [Accessed 13 July 2020].

4. Tian J, Yuan X, Xiao J, Zhong Q, Yang C, Liu B, et al. Clinical characteristics and risk factors associated with COVID-19 disease severity in patients with cancer in Wuhan, China: a multicentre, retrospective, cohort study. Lancet Oncol. 2020;21(7):893-903. Available at: www.thelancet.com/ journals/lanonc/article/PIIS1470-2045(20)30309-0/fulltext. [Accessed: 13 July 2020].

5. Trapani D, Marra A, Curigliano G. The experience on coronavirus disease 2019 and cancer from an oncology hub institution in Milan, Lombardy Region. European Journal of Cancer. 2020 06;132:199-206. https://doi.org/10.1016/j. ejca.2020.04.017

6. Yang K, Sheng Y, Huang C, Jin Y, Xiong N, Jiang K, Lu H, Liu J, Yang J, Dong Y, Pan D, Shu C, Li J, Wei J, Huang Y, Peng L, Wu M, Zhang R, Wu B, Li Y, Cai L, Li G, Zhang T, $\mathrm{Wu}$ G. Clinical characteristics, outcomes, and risk factors for mortality in patients with cancer and COVID-19 in Hubei, 
China: a multicentre, retrospective, cohort study. The Lancet Oncology. 2020 07;21(7):904-913. https://doi.org/10.1016/ s1470-2045(20)30310-7

7. Gatellier L, Matsuda T, Sabapathy K, Dai M, Dewi LKM, Huong TT, Kardinah K, Thuan TV, Park JB, He J, Nansalmaa E, Luvsandorj B, Hwang WYK, Sengar M, Pramesh C, Suzuki T. An Asian Body to Tackle Cancers in Asia - The Asian National Cancer Centers Alliance. Asian Pacific Journal of Cancer Prevention. 2020 05 01;21(5):1207-1212. https://doi.org/10.31557/apjcp.2020.21.5.1207

8. World Health Organization. Coronavirus disease (COVID-19) Situation Report-151 2020. Available at: www.who.int/docs/ default-source/coronaviruse/situation-reports/20200619covid-19-sitrep-151.pdf?sfvrsn=8b23b56e_2. [Accessed: 13 July 2020].

9. Tata Memorial Centre. COVID-19 Webinars. Available at: https://tmc.gov.in/ncg/index.php/covid-webinars [Accessed: 13 July 2020].

10. Rumah Sakit Kanker Dharmais. COVID-19 Webinars. Available at: www.dharmais.co.id/news/58/PASTWEBINAR. [Accessed: 13 July 2020].

11. Shaukat Khanum Memorial Center Hospital and Research Centre, Lahore. Shaukat Khanum Coronavirus Resource Library for Healthcare Providers Shaukat Khanum. Available at: shaukatkhanum.org.pk/coronavirus/. [Accessed: 13 July 2020].

12. Shaukat Khanum Memorial Center Hospital and Research Centre, Lahore. Shaukat Khanum Guidelines for Coronavirus Disease 2019 (COVID-19) Shaukat Khanum2020. Available at: shaukatkhanum.org.pk/wp-content/uploads/2020/04/ SKMT_COVID19_Guidelines_April_10.pdf. [Accessed: 13 July 2020].

13. National Cancer Center Vietnam. K Hospital organizes an online consultation program "Things to know for cancer patients during the COVID-19 pandemic" Vietnam National Cancer Center Hospital. Available at: benhvienk.vn/benhvien-k-to-chuc-chuong-trinh-tu-van-truc-tuyen-nhung-dieucan-biet-cho-nguoi-benh-ung-thu-trong-dai-dich-covid-19nd89049.html. [Accessed: 13 July 2020].

14. National Cancer Center Korea. Korean Cancer SocietyNational Cancer Center announces recommendations for cancer patients based on Corona19 situation Korea National Cancer Center. Available at: ncc.re.kr/prBoardView1.ncc?n wsId=5596\&searchKey=total\&searchValue=\&pageNum=2. [Accessed: 13 July 2020].

15. Djalante R, Lassa J, Setiamarga D, Sudjatma A, Indrawan M, Haryanto B, Mahfud C, Sinapoy MS, Djalante S, Rafliana I, Gunawan LA, Surtiari GAK, Warsilah H. Review and analysis of current responses to COVID-19 in Indonesia: Period of January to March 2020. Progress in Disaster Science. 2020 04;6:100091. https://doi.org/10.1016/j. pdisas.2020.100091

16. Yusuf A. Cancer care in the time of COVID-19-a perspective from Pakistan. ecancermedicalscience. 202004 20;14. https://doi.org/10.3332/ecancer.2020.1026

17. Ministry of Health and Welfare Japan. For the expansion of new coronavirus infectious disease, such as medical treatment using telephone and information communication equipment. Available at: https://www.mhlw.go.jp/content/000621247. pdf. [Accessed: 22 July 2020].

18. Jazieh A, Al Hadab A, Al Olayan A, AlHejazi A, Al Safi F, Al Qarni A, Farooqui F, Al Mutairi N, Alenazi TH. Managing Oncology Services During a Major Coronavirus Outbreak: Lessons From the Saudi Arabia Experience. JCO Global Oncology. 2020 03;(6):518-524. https://doi.org/10.1200/ go.20.00063

19. Liu S, Chan T, Chu Y, Wu JT, Geng X, Zhao N, Cheng W,
Chen E, King C. Comparative Epidemiology of Human Infections with Middle East Respiratory Syndrome and Severe Acute Respiratory Syndrome Coronaviruses among Healthcare Personnel. Chan RW. PLOS ONE. 201603 01;11(3):e0149988. https://doi.org/10.1371/journal. pone. 0149988

20. Liu J, Zheng X, Tong Q, Li W, Wang B, Sutter K, Trilling M, Lu M, Dittmer U, Yang D. Overlapping and discrete aspects of the pathology and pathogenesis of the emerging human pathogenic coronaviruses SARS-CoV, MERS$\mathrm{CoV}$, and 2019-nCoV. Journal of Medical Virology. 2020 05;92(5):491-494. https://doi.org/10.1002/jmv.25709

21. World Health Organization. Summary of probable SARS cases with onset of illness from 1 November 2002 to 31 July 2003. Available at: www.who.int/csr/sars/country/ table2004_04_21/en/. [Accessed: 13 July 2020]..

22. World Health Organization. MERS situation update, January 2020. Available at: www.emro.who.int/pandemic-epidemicdiseases/mers-cov/mers-situation-update-january-2020. html. [Accessed: 13 July 2020]..

23. Xiao J, Fang M, Chen Q, He B. SARS, MERS and COVID-19 among healthcare workers: A narrative review. Journal of Infection and Public Health. 2020 06;13(6):843-848. https:// doi.org/10.1016/j.jiph.2020.05.019

24. Lai X, Wang M, Qin C, Tan L, Ran L, Chen D, Zhang H, Shang K, Xia C, Wang S, Xu S, Wang W. Coronavirus Disease 2019 (COVID-2019) Infection Among Health Care Workers and Implications for Prevention Measures in a Tertiary Hospital in Wuhan, China. JAMA Network Open. 202005 21;3(5):e209666. https://doi.org/10.1001/ jamanetworkopen.2020.9666

25. Shankar A, Saini D, Roy S, Mosavi Jarrahi A, Chakraborty A, Bharti SJ, Taghizadeh-Hesary F. Cancer Care Delivery Challenges Amidst Coronavirus Disease - 19 (COVID-19) Outbreak: Specific Precautions for Cancer Patients and Cancer Care Providers to Prevent Spread. Asian Pacific Journal of Cancer Prevention. 202003 01;21(3):569-573. https://doi.org/10.31557/apjcp.2020.21.3.569

26. TAM CWC, PANG EPF, LAM LCW, CHIU HFK. Severe acute respiratory syndrome (SARS) in Hong Kong in 2003: stress and psychological impact among frontline healthcare workers. Psychological Medicine. 2004 Oct;34(7):11971204. https://doi.org/10.1017/s0033291704002247

27. Um DH, Kim JS, Lee HW, Lee SH. Psychological Effects on Medical Doctors from the Middle East Respiratory Syndrome (MERS) Outbreak : A Comparison of Whether They Worked at the MERS Occurred Hospital or Not, and Whether They Participated in MERS Diagnosis and Treatment. Journal of Korean Neuropsychiatric Association. 2017;56(1):28. https://doi.org/10.4306/jknpa.2017.56.1.28

28. van de Haar J, Hoes LR, Coles CE, Seamon K, Fröhling S, Jäger D, Valenza F, de Braud F, De Petris L, Bergh J, Ernberg I, Besse B, Barlesi F, Garralda E, Piris-Giménez A, Baumann M, Apolone G, Soria JC, Tabernero J, Caldas C, Voest EE. Caring for patients with cancer in the COVID-19 era. Nature Medicine. 202004 16;26(5):665-671. https://doi. org/10.1038/s41591-020-0874-8

29. Noticewala SS, Koong AC, Bloom ES, Choi S, Chronowski G, Ghafar RA, Guadagnolo BA, Gunn GB, Klopp A, Lee P, Li J, Liao Z, Ludmir EB, McAleer MF, Nguyen Q, Ning MS, Robinson IJ, Rosenthal DI, Shah SJ, Woodward WA, Zaebst DJ, Dabaja BS, Das P. Radiation Oncology Strategies to Flatten the Curve During the Coronavirus Disease 2019 (COVID-19) Pandemic: Experience From a Large Tertiary Cancer Center. Advances in Radiation Oncology. 2020 07;5(4):567-572. https://doi.org/10.1016/j.adro.2020.04.038 30. Ramirez PT, Chiva L, Eriksson AGZ, Frumovitz M, Fagotti 
A, Gonzalez Martin A, Jhingran A, Pareja R. COVID-19 Global Pandemic: Options for Management of Gynecologic Cancers. International Journal of Gynecologic Cancer. 2020 03 27;30(5):561-563. https://doi.org/10.1136/ijgc-2020001419

31. Ueda M, Martins R, Hendrie PC, McDonnell T, Crews JR, Wong TL, McCreery B, Jagels B, Crane A, Byrd DR, Pergam SA, Davidson NE, Liu C, Stewart FM. Managing Cancer Care During the COVID-19 Pandemic: Agility and Collaboration Toward a Common Goal. Journal of the National Comprehensive Cancer Network. 2020 04;18(4):366-369. https://doi.org/10.6004/jnccn.2020.7560

32. World Health Organization. COVID-19 Strategy Update 14 April 2020. Available at: www.who.int/docs/default-source/ coronaviruse/covid-strategy-update-14april2020.pdf?sfvrsn $=29$ da3ba0_19\&download=true. [Accessed 13 July 2020].

33. Kassem AM. COVID-19: Mitigation or suppression?. Arab Journal of Gastroenterology. 2020 03;21(1):1-2. https://doi. org/10.1016/j.ajg.2020.04.010

34. Nabi J. COVID-19: what the evidence so far means for containment. World Economic Forum. Available at: www. weforum.org/agenda/2020/04/covid-19-containmentsuppression-strategy/. [Accessed 13 July 2020].

35. Poonia D, Sehrawat A, Gupta M. The Tale of Two C's, Cancer and COVID-19: Oncologists' Viewpoint from India. Asian Pac J Cancer Care. 2020;5(Suppl 2):146. Available at: waocp.com/journal/index.php/apjcc/article/view/411/1422. [Accessed 13 July 2020].

36. OCHA Services. Indonesia Multi-Sectoral Response Plan to COVID-19 (May-October 2020). Available at: reliefweb. int/report/indonesia/indonesia-multi-sectoral-response-plancovid-19-may-october-2020. [Accessed 13 July 2020]..

37. Hoda W, Bharati S, Kumar A, Choudhary P, Shankar A. Socio-Cultural and Economic Impact of Corona Virus on Cancer Patients, caregivers and Survivors. Asian Pac J Cancer Care. 2020;5(Suppl 2):171-173. Available at: waocp.com/journal/index.php/apjcc/article/view/457/1439. [Accessed 13 July 2020].

38. Hollander JE, Carr BG. Virtually Perfect? Telemedicine for Covid-19. New England Journal of Medicine. 2020 04 30;382(18):1679-1681. https://doi.org/10.1056/ nejmp2003539

39. Liu R, Sundaresan T, Reed ME, Trosman JR, Weldon CB, Kolevska T. Telehealth in Oncology During the COVID-19 Outbreak: Bringing the House Call Back Virtually. JCO Oncology Practice. 2020 06;16(6):289-293. https://doi. org/10.1200/op.20.00199

40. Javaid M, Haleem A, Vaishya R, Bahl S, Suman R, Vaish A. Industry 4.0 technologies and their applications in fighting COVID-19 pandemic. Diabetes \& Metabolic Syndrome: Clinical Research \& Reviews. 2020 07;14(4):419-422. https://doi.org/10.1016/j.dsx.2020.04.032

41. Daggubati LC, Eichberg DG, Ivan ME, Hanft S, Mansouri A, Komotar RJ, D'Amico RS, Zacharia BE. Telemedicine for Outpatient Neurosurgical Oncology Care: Lessons Learned for the Future During the COVID-19 Pandemic. World Neurosurgery. 2020 07;139:e859-e863. https://doi. org/10.1016/j.wneu.2020.05.140

42. Bokolo AJ. Exploring the adoption of telemedicine and virtual software for care of outpatients during and after COVID-19 pandemic. Irish Journal of Medical Science (1971 -). 202007 08;. https://doi.org/10.1007/s11845-02002299-z

43. Dai M, Liu D, Liu M, Zhou F, Li G, Chen Z, Zhang Z, You H, Wu M, Zheng Q, Xiong Y, Xiong H, Wang C, Chen C, Xiong F, Zhang Y, Peng Y, Ge S, Zhen B, Yu T, Wang L, Wang H, Liu Y, Chen Y, Mei J, Gao X, Li Z, Gan L, He C, Li Z, Shi
Y, Qi Y, Yang J, Tenen DG, Chai L, Mucci LA, Santillana $\mathrm{M}$, Cai H. Patients with cancer appear more vulnerable to SARS-COV-2: a multi-center study during the COVID-19 outbreak. Cancer Discovery. 202004 28;:CD-20-0422. https://doi.org/10.1158/2159-8290.cd-20-0422

44. Liang W, Guan W, Chen R, Wang W, Li J, Xu K, Li C, Ai Q, Lu W, Liang H, Li S, He J. Cancer patients in SARSCoV-2 infection: a nationwide analysis in China. The Lancet Oncology. 2020 03;21(3):335-337. https://doi.org/10.1016/ s1470-2045(20)30096-6

45. Yu J, Ouyang W, Chua MLK, Xie C. SARS-CoV-2 Transmission in Patients With Cancer at a Tertiary Care Hospital in Wuhan, China. JAMA Oncology. 202007 01;6(7):1108. https://doi.org/10.1001/jamaoncol.2020.0980

46. Zhang L, Zhu F, Xie L, Wang C, Wang J, Chen R, Jia P, Guan H, Peng L, Chen Y, Peng P, Zhang P, Chu Q, Shen Q, Wang Y, Xu S, Zhao J, Zhou M. Clinical characteristics of COVID-19-infected cancer patients: a retrospective case study in three hospitals within Wuhan, China. Annals of Oncology. 2020 07;31(7):894-901. https://doi.org/10.1016/j. annonc.2020.03.296

47. Moujaess E, Kourie HR, Ghosn M. Cancer patients and research during COVID-19 pandemic: A systematic review of current evidence. Critical Reviews in Oncology/ Hematology. 2020 06;150:102972. https://doi.org/10.1016/j. critrevonc.2020.102972

48. World Health Organization. Statement to the Russianlanguage media by Dr Hans Henri P. Kluge, WHO Regional Director for Europe. Available from: www.euro.who.int/en/ about-us/regional-director/statements-and-speeches/2020/ statement-preparing-for-the-autumn-is-a-priority-nowat-the-who-regional-office-for-europe. [Accessed 13 July 2020].

49. Jones D, Neal R, Duffy S, Scott S, Whitaker K, Brain K. Impact on the COVID-19 pandemic on the sympotamtic diagnosis of cancer: the view from primary care. Lancet Oncol. 2020 Jun;21(6):748-750. Available at: www.thelancet. com/pdfs/journals/lanonc/PIIS1470-2045(20)30242-4.pdf. [Accessed 13 July 2020].

50. Richards M, Anderson M, Carter P, Ebert BL, Mossialos E. The impact of the COVID-19 pandemic on cancer care. Nature Cancer. 202005 20;1(6):565-567. https://doi. org/10.1038/s43018-020-0074-y

51. Epic Health Research Network. Preventive Cancer Screenings during COVID-19 Pandemic. Available at: www.ehrn.org/wp-content/uploads/Preventive-CancerScreenings-during-COVID-19-Pandemic.pdf. [Accessed 13 July 2020].

52. Basu P. Healthcare Systems Need to be Organized to Fight Two Pandemics Simultaneously. Asian Pac J Cancer Care. 2020;5(Suppl 1):1-3. Available at: waocp.com/journal/index. php/apjcc/article/view/459/1411. [Accessed 13 July 2020].

53. Del Vecchio Blanco G, Calabrese E, Biancone L, Monteleone G, Paoluzi OA. The impact of COVID-19 pandemic in the colorectal cancer prevention. International Journal of Colorectal Disease. 202006 04; https://doi.org/10.1007/ s00384-020-03635-6

54. Amit M, Tam S, Bader T, Sorkin A, Benov A. Pausing cancer screening during the severe acute respiratory syndrome coronavirus 2pandemic: Should we revisit the recommendations?. European Journal of Cancer. 2020 07;134:86-89. https://doi.org/10.1016/j.ejca.2020.04.016

55. Kuderer N, Choueiri T, Shah D, Shyr Y, Rubinstein S, Rivera D, et al. Clinical Impact on COVID-19 on patients with cancer (CCC19): a cohort study. Lancet. 2020;395(10241):1907-1918. Available at: www.thelancet. com/journals/lancet/article/PIIS0140-6736(20)31187-9/ 
fulltext. [Accessed 13 July 2020].

56. Lee LYW, Cazier JB, Starkey T, Turnbull CD, Kerr R, Middleton G. COVID-19 mortality in patients with cancer on chemotherapy or other anticancer treatments: a prospective cohort study. The Lancet. 2020 06;395(10241):1919-1926. https://doi.org/10.1016/s0140-6736(20)31173-9

57. Waterhouse DM, Harvey RD, Hurley P, Levit LA, Kim ES, Klepin HD, Mileham KF, Nowakowski G, Schenkel C, Davis C, Bruinooge SS, Schilsky RL. Early Impact of COVID-19 on the Conduct of Oncology Clinical Trials and Long-Term Opportunities for Transformation: Findings From an American Society of Clinical Oncology Survey. JCO Oncology Practice. 2020 07;16(7):417-421. https:// doi.org/10.1200/op.20.00275

58. Pramesh C, Badwe RA. Cancer Management in India during Covid-19. New England Journal of Medicine. 2020 05 14;382(20):e61. https://doi.org/10.1056/nejmc2011595

59. The COVID-19 pandemic and the Tata Memorial Centre response. Indian Journal of Cancer. 2020;0(0):0. https://doi. org/10.4103/ijc.ijc_250_20

\section{कब}

This work is licensed under a Creative Commons AttributionNon Commercial 4.0 International License. 